\title{
Flume observations on flow dynamics in Zostera marina (eelgrass) beds
}

\author{
Maria Cristina Gambi ${ }^{1}$, Arthur R. M. Nowell ${ }^{2}$, Peter A. Jumars ${ }^{2}$ \\ ' Laboratorio di Ecologia del Benthos, Stazione Zoologica 'Anton Dohrn' di Napoli, I-80077 Ischia (Napoli), Italy \\ ${ }^{2}$ School of Oceanography, WB-10 University of Washington, Seattle, Washington 98195, USA
}

\begin{abstract}
Flow dynamics in Zostera marina L. (eelgrass) were studied in a large seawater flume. Velocity and turbulence intensity profiles were measured at 3 free-stream flow velocities $[5,10$ and $\left.20 \mathrm{~cm} \mathrm{~s}^{-1}\right)$, at 5 shoot densities $\left(1200,1000,800,600\right.$ and 400 shoots $\left.\mathrm{m}^{-2}\right)$, and at 5 along-stream positions relative to the leading edge of the eelgrass bed $(10 \mathrm{~cm}$ upstream of the bed; $25,50,75$ and $100 \mathrm{~cm}$ downstream of the leading edge of the bed). All the profiles (75) above the canopy or over bare sand fitted a log-profile relationship. At all densities and ambient velocities tested, mean velocity increased above the canopy, while within the bed water speed dropped distinctly below the canopy-water interface. Depending on shoot density, water speed was from 2 to 10 times lower under the canopy than upstream of the seagrass bed. Shear velocities (U*) above the canopy were 2 to 11 times greater than outside the bed at equivalent height, and increased significantly with distance into the meadow. No significant differences among densities were observed. Turbulence intensity showed a dramatic increase in all the profiles at the canopy-water interface, a significant increase with distance into the bed, but showed no significant differences between densities. Fluid flux within the bed decreased significantly with distance into the meadow, but exhibited no significant dependence on density. Downstream, vertically integrated fluid flux at $100 \mathrm{~cm}$ into the bed ranged between 14.7 and $40.6 \%$ of upstream values. The least flux reduction occurred at the highest velocity $\left(20 \mathrm{~cm} \mathrm{~s}^{-1}\right)$. Trends in shear velocity and turbulence intensity show clearly that within the bed one can distinguish 2 dynamically different environments. The 'canopy-water interface' habitat is characterized by high shear stress and high turbulence intensity; the 'below-canopy' habitat is characterized by low shear stress and a reduction of turbulence intensity.
\end{abstract}

\section{INTRODUCTION}

Just as terrestrial plant communities modify air flow around themselves and within their canopies (Oliver 1971, Shaw et al. 1974, 1983, Cionco 1983), in marine environments seagrass and macroalgal beds exert strong effects on hydrodynamics (Ott 1967, Fonseca et al. 1983, Jackson \& Winant 1983). Plants bend when a current or a wave passes; thereby deflecting the flow over or around the vegetation. Further, shoots greatly reduce current speed by extracting fluid momentum (Madsen \& Warnke 1983). This process creates a lowenergy microenvironment (Ginsburg \& Lowenstam 1958) that can enhance deposition of suspended material and affect benthic community structure (Peterson et al. 1984).

In seagrass beds, evidence of this phenomenon is mostly indirect, from sediment analysis and plant and animal distributions within meadows. Sediments inside seagrass beds are richer in silt and clay fractions and less well sorted than outside the beds (Ginsburg \& Lowenstam 1958, Scoffin 1970, Orth 1973, 1977, Jeudy de Grissac 1984, Eckman 1987). A large variety of organisms, especially juvenile stages, find shelter in seagrass meadows (defined for this reason as 'nurseries') from physical factors and predators and find food (Den Hartog 1977, Kikuchi 1980, Ogden 1980). These juvenile organisms, as well as adults, generally show microhabitat preferences that can be attributed to flow micro-environments created by the spatial heterogeneity of seagrass blades (Fresi et al. 1982. Stoner \& Lewis 1985, Casola et al. 1987).

There are few direct evaluations and manipulations of hydrodynamics and its influences on benthic populations in seagrass. Thistle et al. (1984) demonstrated that abundances of harpacticoid copepods were enhanced by perturbations in flow by isolated shoots (natural and mimic) of the seagrass Syringodium filiforme. Eckman 
(1987) also suggested that hydrodynamics in eelgrass meadows are more important than predation in influencing abunclances of recruits of 2 bivalve species and stressed the important role of plant density. The mechanisms of flow modification, however, are not yet well visualized and quantified. Field research has concerned Zostera marina (Ackerman 1983, 1986, Fonseca et al. 1983, Eckman 1987) and the Mediterranean seagrass Posidonia oceanica (Gambi 1986, Gambi et al. in press). In these papers, however, flow dynamics are not described and discussed in detail.

In the few flume studies, Zostera marina, Thalassia testudinum. Halodule wrighti and Syringodium filiforme have been considered (Fonseca et al. 1983, Fonseca \& Fisher 1986). Results of these flume observations, however, cannot be generalized because flume design and experimental conditions generally were not dynamically similar to field flow conditions (Nowell \& Jumars 1987). In particular, the plants utilized were too large in relation to flume size, and both their individual size and their arrangement inside the flume caused flow blockage. Thus, both qualitative and quantitative observations may have been strongly biased.

With marine phanerogams, reproducing dynamic similarity in flumes is difficult because of plant dimensions and flume constraints. We carefully compromised the constraints of plant and flume size to approximate dynamic similarity in a large seawater flume with small, juvenile plants, in order to analyze the mechanism of flow modification, quantify flow and flux reduction and estimate turbulence intensity in Zostera marina beds.

Our expectations, based on a critical analysis of previous studies and on our preliminary dye visualization, were: that the plant assemblage would deflect flow above the canopy and around the sides of the bed. reducing flow speed and fluid flux through the seagrass bed; that current baffling and flux reduction would be correlated with density of plant shoots and distance into the meadow from the leading edge of the bed; and that conversion of kinetic energy of the streamwise velocity $(\overline{\mathrm{U}})$ into turbulent kinetic energy, due to canopy flow disruption, would be correlated with plant shoot density and distance into the meadow.

\section{MATERIALS AND METHODS}

Observations and measurements were performed in a large racetrack flume at the Friday Harbor Laboratories (San Juan Island, Washington, USA). Total length of the flume is $10 \mathrm{~m}$, working section $8 \mathrm{~m}$, total height $3 \mathrm{~m}$, total width $2 \mathrm{~m}$, working section width $75 \mathrm{~cm}$ and maximum working depth $30 \mathrm{~cm}$. Speed is fully adjustable (to over $100 \mathrm{~cm} \mathrm{~s}^{-1}$ ), and flow direction is reversible (Nowell et al. in press).

Zostera marina plants were collected in a shallow stand of a natural, subtidal bed that extended from 40 to $70 \mathrm{~cm}$ below MLLW; the stand had a mean and standard deviation in plant density of $508 \pm 117$ shoots $\mathrm{m}^{-2}$ and a mean ( $\pm \mathrm{SD}$ ) canopy height of $25.7 \pm 8.3 \mathrm{~cm}$ (Gambi 1988). Tidal current, measured using a Marsh McBirney (mod. 511) electromagnetic current meter during ebb and flood tide in August 1986, ranged from 9 to $13 \mathrm{~cm} \mathrm{~s}^{-1}$ (no wind and wave action; Gambi \& Lorenti 1988 , Gambi in press). Bulk flow Reynolds number (Re $=u d / v$, where $\mathrm{u}=$ mean velocity, $\mathrm{d}=$ water depth, $\mathrm{v}=$ kinematic viscosity) varied from 400000 to 700000 , depending on tidal stage. Reynolds number for the Zostera bed was calculated using as its 'length scale' the square root of the product of mean canopy height $(h)$ and mean distance $(\mathrm{d})$ between shoots $(\sqrt{\mathrm{hd}})$. This length scale was considered a better evaluation of Re in seagrass beds than a purely vertical or horizontal one because it permits dynamic discrimination of 2 beds with the same canopy height but different plant density. At $\overline{\mathrm{U}}$ of about $10 \mathrm{~cm} \mathrm{~s}^{-1}$, mean canopy height $=25 \mathrm{~cm}$ and mean density $=500$ shoots $\mathrm{m}^{-2}$ (mean distance between shoots $=2.6 \mathrm{~cm}$ ) the 'in situ' Zostera Re was 80000 .

Only small, juvenile plants (total length less than $16 \mathrm{~cm}$ i Table 1), were selected for flume experiments.

Table 1. Zostera marina. Phenological parameters and densities of shoots utilized in flume experiments. Leaf area index: photosynthetic tissue area expressed in $\mathrm{m}^{2} \mathrm{~m}^{-2}$ Numbers are means \pm standard deviations

\begin{tabular}{|lc|}
\hline No. of shoots measured & 20 \\
Sheath length $(\mathrm{cm})$ & $3.68 \pm 0.47$ \\
Leaf height $(\mathrm{cm})$ & $7.9 \pm 3.5$ \\
Leaf width $(\mathrm{cm})$ & $0.28 \pm 0.04$ \\
Canopy height $(\mathrm{cm})$ & $11.44 \pm 2.47$ \\
No. leaves/shoot & $3.9 \pm 0.76$ \\
Leaf area/shoot $\left(\mathrm{cm}^{2}\right)$ & $9.06 \pm 3.4$ \\
Density tested $\left(\mathrm{shoots}^{-2}\right)$ & $1200 ; 1.10$ \\
$\quad$ and leaf area index $\left(\mathrm{m}^{2} \mathrm{~m}^{-2}\right)$ & $1000 ; 0.90$ \\
& $800 ; 0.72$ \\
& $600 ; 0.54$ \\
& $400: 0.36$ \\
\hline
\end{tabular}

Plants were cleaned of epiphytes, and some phenological parameters were measured (Table 1). The flume was filled to a height of $4 \mathrm{~cm}$ with clean sand (mean grain size $150 \mu \mathrm{m}$ ). Plants were then inserted, with their rhizomes, in the sandy bottom $4 \mathrm{~m}$ from the upstream end of the flume test section, at which point the boundary layer over the sand bed was fully developed. Zostera plants were haphazardly placed in the center of the flume at least $30 \mathrm{~cm}$ from each of the sidewalls; the grass bed was $15 \mathrm{~cm}$ wide and $100 \mathrm{~cm}$ long (Fig. 1A). Water depth varied between 22 and $25 \mathrm{~cm}$, and 8 to 


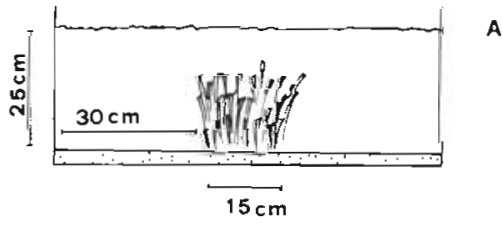

B

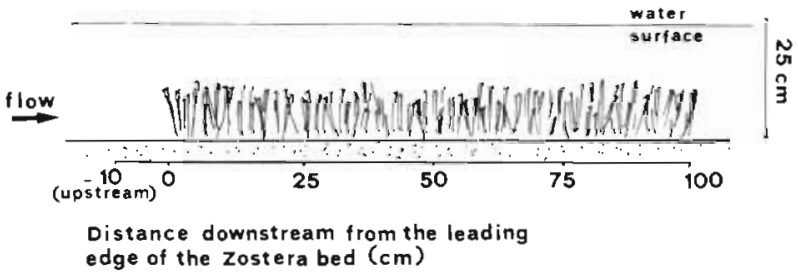

Fig. 1 (A) Location of Zostera marina bed inside a crosssection of the flume. (B) Locations of the 5 along-stream velocity profiles relative to the leading edge of the bed

$10 \mathrm{~cm}$ of water extended above the plant canopy; water thus could pass above and around the grass bed. Density of the bed was manipulated by adding and removing plants to reach the following densities (no. shoots $\mathrm{m}^{-2}$ ): $1200,1000,800,600$ and 400 .

Flow measurements were made for each bed density at 3 free-stream velocities: 5,10 and $20 \mathrm{~cm} \mathrm{~s}^{-1}$. Bulk flow Re number ranged between 125000 and 500000 . The Re number of the Zostera bed varied between 20000 (highest density and lowest flow velocity) and 110000 (lowest density and highest flow). These values approximate those calculated for the natural Zostera bed at the same ambient velocity.

At each density and ambient velocity, velocity profiles were measured in the center of the cross-stream axis of the flume $10 \mathrm{~cm}$ upstream of the bed, over bare sand (also referred to as 'controls'), and 25, 50, 75 and $100 \mathrm{~cm}$ downstream from the leading edge of the bed, within the bed itself (Fig. 1B). Temperature was measured before and during flow measurements and varied between 10 and $12{ }^{\circ} \mathrm{C}$.

Vertical profiles of velocity were measured starting $20 \mathrm{~cm}$ above the bottom and then downward in increments of $2 \mathrm{~cm}$ to the top of the leaf canopy. Below this point velocity was sampled every centimeter down to $1 \mathrm{~cm}$ from the bottom. An entire velocity profile consisted of 11 to 14 measurements. Above the Zostera canopy water velocity was measured with a 2 -axis laser-Doppler velocimeter (LDV, TSI System 9100-8) (Hill et al. 1989). Inside the canopy (where the Zostera leaves interfered with the LDV) flow was measured using a hot-film anemometer (Thermo-Systems Inc., constant temperature mod. 10122 T1.5; and hot-conical quartz probe mod. 1231). Probes were calibrated with the LDV prior to use $\left(r^{2}=0.97\right.$ and 0.99 for the 2 probes, respectively)
Instantaneous velocity (u) may be expressed as the sum $u=\bar{u}+u^{\prime}$, where $\bar{u}$ is mean velocity and $u^{\prime}$ the instantaneous velocity fluctuation. At each point we measured $u$ and the streamwise rms $u^{\prime}$. The turbulence intensity was calculated as

$$
\frac{\mathrm{rms} \mathrm{u}^{\prime}}{\overline{\mathrm{u}}(\mathrm{z})} \cdot 100
$$

As a consistent velocity scale easily convertible to bed shear stress $\left(\tau_{0}\right)$, fluid dynamicists often use 'shear velocity' (U*): $U^{*} * \sqrt{\tau_{0} / \rho}$, where $\rho=$ fluid density. Shear velocity was determined from the KarmanPrandtl log-profile relationship:

$$
\overline{\mathrm{U}}(\mathrm{z})=\frac{\mathrm{U} *}{\mathrm{~K}} \ln \frac{\mathrm{z}}{\mathrm{z}_{\mathrm{o}}}
$$

where $K=$ von Karman's constant $(0.41) ; \bar{U}(z)=$ mean velocity at depth $z ; z_{0}=$ roughness height. Leastsquares regression of $\ln z$ vs $\bar{U}$ was used to calculate $\mathrm{U} *$ and $z_{0}$. It was calculated only over bare sand and over the canopy. Under the canopy, flow departed from the classical log profile.

Total flux for each velocity profile was calculated only up to $20 \mathrm{~cm}$ from the bottom as $\int_{z=0}^{z=\frac{20}{U}} \mathrm{dz}$, because water speed measurements were not extended higher (Fig. 3A, B, C). The proportion of flux at different densities and positions within the bed was the ratio of the area under any given profile $\left(\int_{z=1}^{z=20} u(i) d z\right)$ to the area under the upstream (control) profile $\left(\int_{z=1}^{z=20} u(c) d z\right)$. Percentage of flux reduction was ( 1 - flux proportion) 100 .

Partial correlation coefficients for $U *$, percentage of flux reduction and turbulence intensity were calculated across densities and bed positions (Table 5).

\section{RESULTS}

Of the 75 velocity profiles fitting the log-profile relationship, $70 \%$ have $\mathrm{r}^{2}>0.90$; all are significant at $\mathrm{p}$ $<0.05$ and $90 \%$ at $p<0.01$. There are trends common to all the profiles. An increase in $\overline{\mathrm{U}}$ above the canopy relative to upstream control profiles at identical heights occurred at all 4 positions within the bed, at all densities and free-stream velocities tested. This increase averaged $0.78 \pm 0.09$ (SD) $\mathrm{cm} \mathrm{s}^{-1}$ at a free stream $\overline{\mathrm{U}}=5 \mathrm{~cm} \mathrm{~s}^{-1} ; 1.1 \pm 0.21 \mathrm{~cm} \mathrm{~s}^{-1}$ at $10 \mathrm{~cm} \mathrm{~s}^{-1}$ and $1.5 \pm 0.54 \mathrm{~cm} \mathrm{~s}^{-1}$ at $20 \mathrm{~cm} \mathrm{~s}^{-1}$. Current speeds within the canopy were reduced at all densities. At all velocities and densities tested, current speed decreased with increasing distance from the leading edge of the bed (Fig. 2A, B, C). This was particularly evident between 25 and $50 \mathrm{~cm}$ into the bed; thereafter, little 

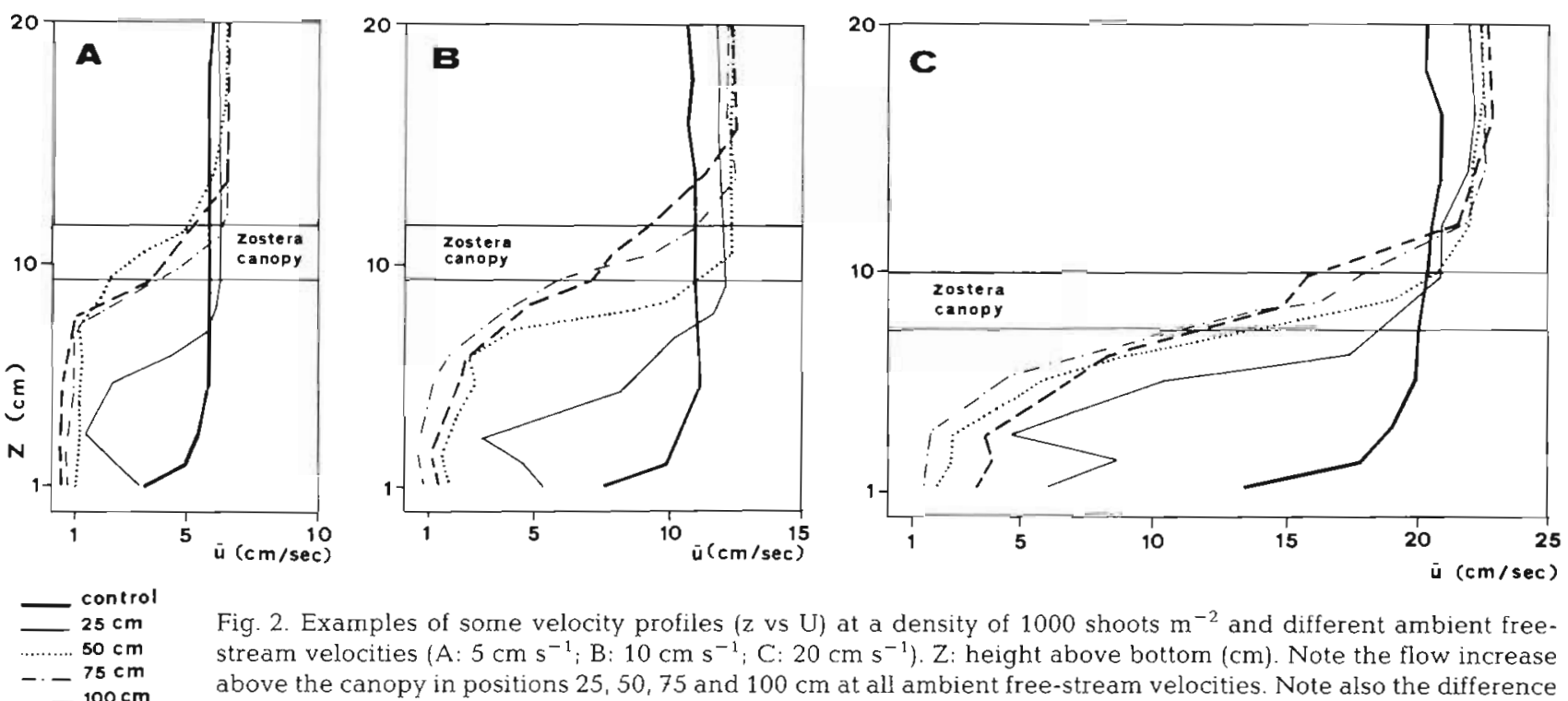

Fig. 2. Examples of some velocity profiles ( $\mathrm{z}$ vs U) at a density of 1000 shoots $\mathrm{m}^{-2}$ and different ambient freestream velocities $\left(A: 5 \mathrm{~cm} \mathrm{~s}^{-1} ; B: 10 \mathrm{~cm} \mathrm{~s}^{-1} ; C: 20 \mathrm{~cm} \mathrm{~s}^{-1}\right)$. Z: height above bottom $(\mathrm{cm})$. Note the flow increase above the canopy in positions $25,50,75$ and $100 \mathrm{~cm}$ at all ambient free-stream velocities. Note also the difference in shape between the boundary layer at position $25 \mathrm{~cm}$ and all the other positions

systematic change occurred. As a consequence, 3 boundary layers formed: one over the bed, one on the underside of the leaf canopy and one over the leaf canopy. The different shape of the flow profile at position $25 \mathrm{~cm}$ was probably related to Zostera marina plant morphology. The bases of the leaves in this plant are enveloped by the sheath of the oldest leaf; these sheaths are more rigid than the leaves and bend less under current.

At $100 \mathrm{~cm}$ within the meadow, speed was 10 to $50 \%$ (according to shoot density) of comparable values in the upstream control position. In order to compare different densities we normalized velocity profiles by dividing $\bar{U}$ at a given depth $z$ by $\bar{U}$ at $z=20 \mathrm{~cm}$ (Fig. 3). At $5 \mathrm{~cm} \mathrm{~s}^{-1}$ the profiles of all densities collapse almost onto the same curve, except for a few points below the canopy and for the lowest density ( 400 shoots $\mathrm{m}^{-2}$; Fig. 3A). At $10 \mathrm{~cm} \mathrm{~s}^{-1}$ the trends are similar but differences between lower and higher densities are more pronounced (Fig. 3B). At $20 \mathrm{~cm} \mathrm{~s}^{-1}$, differences are evident even between the 2 highest densities (Fig. 3C). A similiar trend occurred also in other positions within the bed (not shown).

Shear velocity (U*) values in the upstream, control position increased with free-stream velocity as expected (Table 2). At $5 \mathrm{~cm} \mathrm{~s}^{-1}$ they were the most variable, probably because low flows are more sensitive to bottom roughness. At 5 and $10 \mathrm{~cm} \mathrm{~s}^{-1}$ the upstream values were one order of magnitude lower than values above the canopy, while at $20 \mathrm{~cm} \mathrm{~s}^{-1}$ the upstream values were 2 to 11 times lower. At all the free-stream velocities, the U* values above canopy increased significantly with increasing distance into the bed, and slightly but not significantly with density (Table 5)
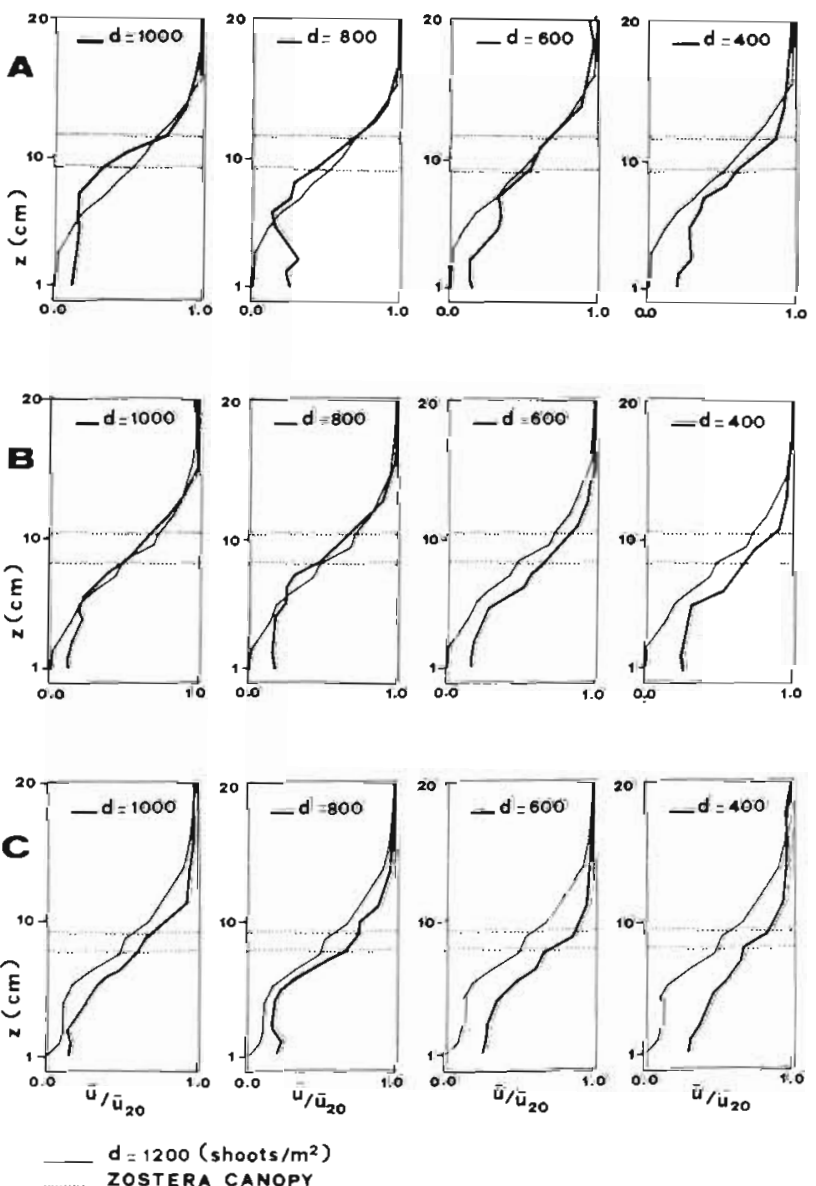

Fig. 3. Normalized profiles at $100 \mathrm{~cm}$ into the bed among different densities and ambient free-stream velocities $(A: 5 \mathrm{~cm}$ $\mathrm{s}^{-1} ; \mathrm{B}: 10 \mathrm{~cm} \mathrm{~s}^{-1}$; $\left.: 20 \mathrm{~cm} \mathrm{~s}^{-1}\right)$. To aid comparison, thin lines show profiles obtained at the highest shoot density (1200 shoots $\mathrm{m}^{-2}$ ) at each flow velocity 
Table 2. Shear velocity $(U *$ ) values at different free-stream velocities, shoot densities and positions outside and over the Zostera marina bed

\begin{tabular}{|c|c|c|c|c|c|}
\hline Density (shoots $\mathrm{m}^{-2}$ ) & Upstream & $25 \mathrm{~cm}$ & $50 \mathrm{~cm}$ & $75 \mathrm{~cm}$ & $100 \mathrm{~cm}$ \\
\hline \multicolumn{6}{|c|}{ Free-stream velocity $5 \mathrm{~cm} \mathrm{~s}^{-1}$} \\
\hline 1200 & $0.175 \cdots$ & $2.22 \cdots$ & $3.32^{\cdots}$ & $3.08^{*}$ & $1.99^{\cdots}$ \\
\hline 1000 & $0.513^{*}$ & $2.68^{\circ}$ & $3.27^{\circ}$ & $4.20^{\cdots}$ & $3.86^{\cdots}$ \\
\hline 800 & $0.253^{\circ}$ & $2.52^{\cdots}$ & $4.50^{\circ}$ & $2.86^{*}$ & $2.60^{\cdots}$ \\
\hline 600 & $0.283^{*}$ & $0.688^{\cdots}$ & $1.93^{*} \cdot$ & $1.93^{*}$ & $1.95^{\cdots}$ \\
\hline 400 & $0.512 \cdots$ & $2.39^{\cdots}$ & $3.11^{\circ}$ & $3.41^{\cdots}$ & $2.80^{\circ}$ \\
\hline \multicolumn{6}{|c|}{ Free-stream velocity $10 \mathrm{~cm} \mathrm{~s}^{-1}$} \\
\hline 1200 & $0.492 *$ & $4.17^{\circ}$ & $7.24^{\cdots}$ & $4.83^{\cdots}$ & $4.17^{\cdots} \cdot$ \\
\hline 1000 & $0.774^{\circ}$ & $3.34^{\cdots}$ & $6.62 \cdots$ & $6.16^{\circ}$ & $4.74^{\cdots}$ \\
\hline 800 & $0.550^{\cdots}$ & $4.82^{\cdots}$ & $5.49^{\circ}$ & $5.10^{\cdots}$ & $4.75^{\cdots}$ \\
\hline 600 & $0.427^{\cdots}$ & $1.50^{\circ}$ & $2.38^{\circ}$ & $4.34^{\cdots}$ & $3.58 \cdots$ \\
\hline 400 & $0.541 \cdots$ & $4.18^{\cdots}$ & $4.78^{\circ}$ & $5.07 \cdots$ & $4.33^{\cdots}$ \\
\hline \multicolumn{6}{|c|}{ Free-stream velocity $20 \mathrm{~cm} \mathrm{~s}^{-1}$} \\
\hline 1200 & $1.07^{\cdots}$ & $8.83^{\cdots}$ & $10.91 \cdots$ & $7.48^{*}$ & $7.04 \cdots$ \\
\hline 1000 & $1.10^{\cdots}$ & $6.30^{\cdots}$ & $10.84 \cdots$ & $9.78^{*}$ & $7.49^{*}$ \\
\hline 800 & $1.16^{\cdots}$ & $2.71 \cdots$ & $5.40 \cdots$ & $8.27^{\cdots}$ & $7.17^{\cdots}$ \\
\hline 600 & $1.01 \cdots$ & $5.24^{\cdots}$ & $5.44^{\cdots}$ & $11.70^{*} \cdot$ & $8.47^{\cdots}$ \\
\hline 400 & $1.18^{\circ}$ & $3.08^{\cdots}$ & $3.72 \cdots$ & $6.19^{*}$ & $5.52 \cdots$ \\
\hline
\end{tabular}

Table 3. Mean turbulence intensity, expressed as $\frac{\mathrm{rms} \mathrm{u}^{\prime}}{\overline{\mathrm{u}}(\mathrm{z})} 100$, along the whole profile, at different densities, positions and ambient free-stream velocities

\begin{tabular}{|c|c|c|c|c|c|}
\hline Density (shoots $\mathrm{m}^{-2}$ ) & Upstream & $25 \mathrm{~cm}$ & $50 \mathrm{~cm}$ & $75 \mathrm{~cm}$ & $100 \mathrm{~cm}$ \\
\hline \multicolumn{6}{|c|}{ Free-stream velocity $5 \mathrm{~cm} \mathrm{~s}^{-1}$} \\
\hline 1200 & 5.1 & 13.8 & 18.3 & 19.3 & 28.7 \\
\hline 1000 & 7.1 & 13.7 & 17.2 & 23.2 & 29.5 \\
\hline 800 & 6.4 & 10.2 & 13.2 & 16.7 & 22.7 \\
\hline 600 & 8.3 & 12.6 & 16.1 & 25.4 & 27.2 \\
\hline 400 & 6.4 & 12.3 & 14.6 & 19.5 & 15.8 \\
\hline \multicolumn{6}{|c|}{ Free-stream velocity $10 \mathrm{~cm} \mathrm{~s}^{-1}$} \\
\hline 1200 & 5.9 & 14.7 & 22.2 & 27.3 & 28.2 \\
\hline 1000 & 6.4 & 10.8 & 16.8 & 28.3 & 27.8 \\
\hline 800 & 5.7 & 9.3 & 16.0 & 27.3 & 29.2 \\
\hline 600 & 6.9 & 10.2 & 14.2 & 21.3 & 25.0 \\
\hline 400 & 6.3 & 10.3 & 14.9 & 19.6 & 15.9 \\
\hline \multicolumn{6}{|c|}{ Free-stream velocity $20 \mathrm{~cm} \mathrm{~s}^{-1}$} \\
\hline 1200 & 5.4 & 13.9 & 17.7 & 27.3 & 21.4 \\
\hline 1000 & 5.5 & 12.6 & 15.2 & 25.8 & 20.5 \\
\hline 800 & 5.9 & 8.7 & 12.0 & 24.8 & 20.9 \\
\hline 600 & 5.8 & 10.0 & 13.0 & 18.3 & 17.1 \\
\hline 400 & 6.1 & 8.2 & 9.4 & 13.0 & 14.4 \\
\hline
\end{tabular}

Data on turbulence intensity are given in Table 3. Only a few profiles are shown (Fig. $4 \mathrm{~A}, \mathrm{~B}$ and $\mathrm{C}$, including profiles for the highest and the lowest shoot densities) but all had common features. Turbulence intensity, both upstream and within the grass bed, did not seem to vary strongly with free-stream velocity. Maxima of turbulence intensity occurred at the water-canopy interface. Turbulence intensity below the canopy decreased slightly but was always greater than at equivalent heights upstream. With increasing distance into the grass bed, mean turbulence intensity increased as did the thickness of the overlying water layer affected by canopy flow disruption. As observed for speed reduction (see above), this was particularly evident between positions $25 \mathrm{~cm}$ and $50 \mathrm{~cm}$; after the latter location, little systematic change occurred. When tested, however, mean turbulence intensity 

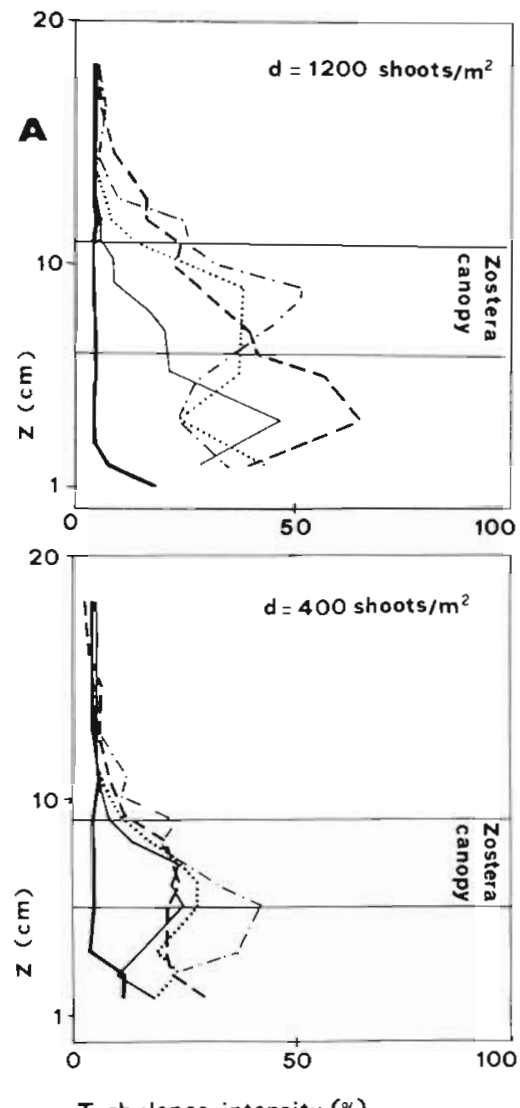

Turbulence intensity $(\%)$

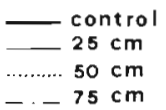$$
--75 \mathrm{~cm}
$$$$
--100 \mathrm{~cm}
$$

showed significant increases with distance into the bed (except at $5 \mathrm{~cm} \mathrm{~s}^{-1}$, Table 5). Density differences and interactions were not significant (Table 5).

Percentages of flux reduction (Table $4 \mathrm{~A}$ ) within the bed relative to upstream flux showed minima at a freestream velocity of $20 \mathrm{~cm} \mathrm{~s}^{-1}$. At all free-stream velocities, relative flux decreased, but not significantly, with shoot density, and significantly with distance into the meadow (Table 5). From profiles in Fig. 4A, B, C $(100 \mathrm{~cm}$ within the bed) we calculated flux reduction below canopy among different densities (Tabie 4B). Below the canopy, flux decreased with shoot density; at $5 \mathrm{~cm} \mathrm{~s}^{-1}$ we observed a difference of $45.8 \%$ between 400 and 1000 shoots $\mathrm{m}^{-2}$, while at $10 \mathrm{~cm}$ and $20 \mathrm{~cm} \mathrm{~s}^{-1}$, a difference of 38.9 and $58.8 \%$ was observed between 400 and 1200 shoots $\mathrm{m}^{-2}$, respectively (Table $4 \mathrm{~B}$ ).

\section{DISCUSSION}

Shear velocity and turbulence intensity trends show clearly that within the bed one can distinguish 2 dynamically different environments: that at the
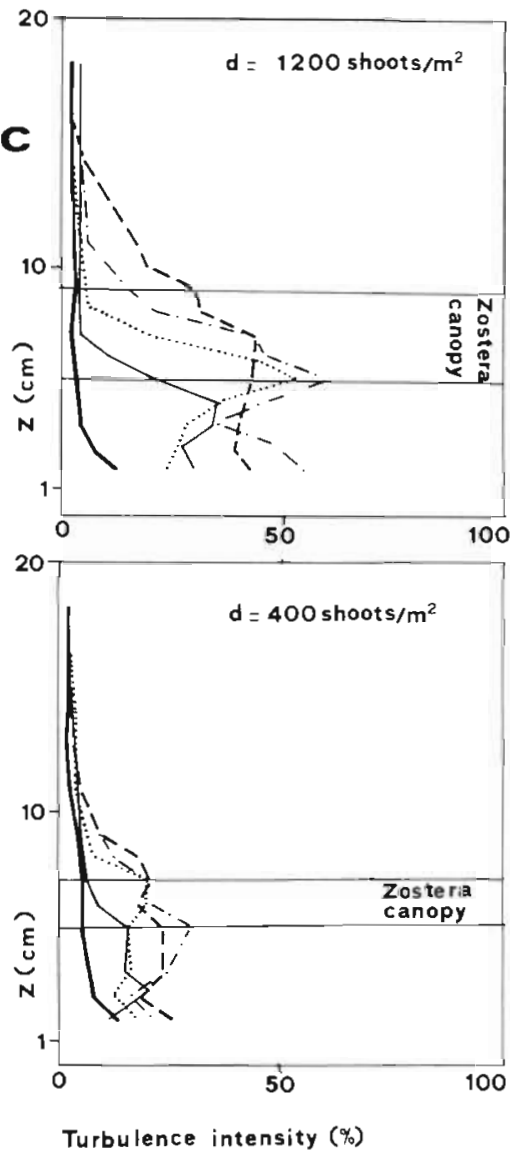

Turbulence intensity (\%) 
Table 4A. Percentages of water flux reduction at different free-stream velocities, shoot densities and positions

\begin{tabular}{|c|c|c|c|c|}
\hline $\begin{array}{l}\text { Density } \\
\text { (shoots } \mathrm{m}^{-2} \text { ) }\end{array}$ & $25 \mathrm{~cm}$ & $50 \mathrm{~cm}$ & $75 \mathrm{~cm}$ & $100 \mathrm{~cm}$ \\
\hline \multicolumn{5}{|c|}{ Free-stream velocity $5 \mathrm{~cm} \mathrm{~s}^{-1}$} \\
\hline 1200 & 20.7 & 38.3 & 43.1 & 35.2 \\
\hline 1000 & 11.0 & 31.4 & 26.7 & 40.6 \\
\hline 800 & 7.55 & 19.9 & 21.4 & 28.9 \\
\hline 600 & 3.58 & 12.3 & 13.7 & 20.3 \\
\hline 400 & 9.6 & 18.7 & 29.7 & 21.8 \\
\hline \multicolumn{5}{|c|}{ Free-stream velocity $10 \mathrm{~cm} \mathrm{~s}^{-1}$} \\
\hline 1200 & 11.5 & 30.0 & 30.7 & 31.5 \\
\hline 1000 & 5.6 & 20.6 & 30.9 & 31.5 \\
\hline 800 & 12.3 & 23.0 & 31.4 & 32.6 \\
\hline 600 & 0.9 & 9.8 & 19.5 & 20.5 \\
\hline 400 & 8.0 & 19.4 & 27.6 & 22.1 \\
\hline \multicolumn{5}{|c|}{ Free-stream velocity $20 \mathrm{~cm} \mathrm{~s}^{-1}$} \\
\hline 1200 & 8.9 & 16.6 & 19.9 & 34.2 \\
\hline 1000 & 10.4 & 19.6 & 23.16 & 21.0 \\
\hline 800 & 2.2 & 13.4 & 21.0 & 18.3 \\
\hline 600 & 5.2 & 13.9 & 21.7 & 19.8 \\
\hline 400 & 2.0 & 8.3 & 15.2 & 14.7 \\
\hline
\end{tabular}

Table $4 \mathrm{~B}$. Percentage of flux reduction, below the canopy, comparing different densities at the position $100 \mathrm{~cm}$ downstream of the leading edge of the bed

\begin{tabular}{|c|c|c|c|c|c|}
\hline \multicolumn{6}{|c|}{ Free-stream velocity $5 \mathrm{~cm} \mathrm{~s}^{-1}$} \\
\hline Density & 400 & 600 & 800 & 1000 & 1200 \\
\hline 400 & - & & & & \\
\hline 600 & 15.2 & - & & & \\
\hline 800 & 28.4 & 15.5 & - & & \\
\hline 1000 & 45.8 & 36.1 & 24.3 & - & \\
\hline 1200 & 39.3 & 28.4 & 15.2 & 10.7 & - \\
\hline \multicolumn{6}{|c|}{ Free-stream velocity $10 \mathrm{~cm} \mathrm{~s}^{-1}$} \\
\hline Density & 400 & 600 & 800 & 1000 & 1200 \\
\hline 400 & - & & & & \\
\hline 600 & 0.2 & - & & & \\
\hline 800 & 30.1 & 26.4 & - & & \\
\hline 1000 & 31.0 & 27.4 & 1.3 & - & \\
\hline 1200 & 38.9 & 35.7 & 12.6 & 11.4 & - \\
\hline \multicolumn{6}{|c|}{ Free-stream velocity $20 \mathrm{~cm} \mathrm{~s}^{-1}$} \\
\hline Density & 400 & 600 & 800 & 1000 & 1200 \\
\hline 400 & - & & & & \\
\hline 600 & 13.4 & - & & & \\
\hline 800 & 33.4 & 14.5 & - & & \\
\hline 1000 & 36.6 & 18.7 & 4.9 & - & \\
\hline 1200 & 57.8 & 36.6 & 36.6 & 33.4 & - \\
\hline
\end{tabular}

energy can return to the bed in a deceleration at the rear or can be dissipated in the wake to the rear of the bed itself (and in part eventually to heat).

As regards flux within the canopy, a 'density
Table 5. Partial correlation coefficients ( $r$ ) of shear velocity, turbulence intensity and flux reduction with density of shoots (D) and distance into the meadow $(P)$, and with $D^{2}, P^{2}$ and $D P$ (density-position interaction)

\begin{tabular}{|c|c|c|c|c|c|}
\hline $\mathrm{U}\left(\mathrm{cm} \mathrm{s}^{-1}\right)$ & $\mathrm{D}$ & $\mathrm{P}$ & $D^{2}$ & $\mathrm{p}^{2}$ & DP \\
\hline 5 & 0.07 & $0.50^{\circ}$ & 0.02 & 0.47 & 0.14 \\
\hline 10 & 0.05 & $0.54^{\circ}$ & 0.13 & $0.52^{\circ}$ & 0.10 \\
\hline 20 & 0.29 & $0.57^{\circ}$ & 0.10 & $0.49^{\circ}$ & 0.38 \\
\hline
\end{tabular}

(B) Vertical mean turbulence intensity (Table 3 )

\begin{tabular}{lccccc}
$\mathrm{U}\left(\mathrm{cm} \mathrm{s}^{-1}\right)$ & $D$ & $P$ & $D^{2}$ & $P^{2}$ & $D P$ \\
\hline 5 & 0.22 & 0.24 & 0.12 & 0.04 & 0.09 \\
10 & 0.35 & $0.68 \cdots$ & 0.17 & 0.48 & 0.05 \\
20 & 0.39 & $0.64 \cdots$ & 0.19 & $0.50^{*}$ & 0.16
\end{tabular}

(C) Percentage of flux reduction (Table $4 \mathrm{~A}$ )

\begin{tabular}{lccccc}
$U\left(\mathrm{~cm} \mathrm{~s}^{-1}\right)$ & $D$ & $P$ & $D^{2}$ & $P^{2}$ & $D P$ \\
\hline 5 & 0.30 & $0.66 \cdots$ & 0.47 & $0.55^{\bullet}$ & 0.03 \\
10 & 0.03 & $0.73 \cdots$ & 0.12 & $0.62 \cdots$ & 0.18 \\
20 & 0.32 & $0.69 \cdots$ & 0.15 & $0.52 \cdot$ & 0.04 \\
Correlation coefficient (r): significant ${ }^{*} p<0.05$ & \\
$\cdots p<0.01$ &
\end{tabular}

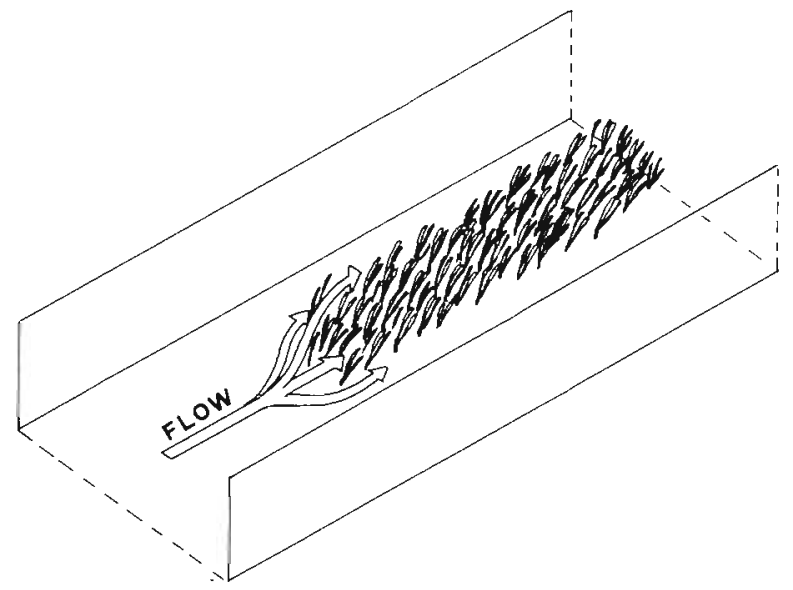

Fig. 5. Flow deflection and acceleration around the bed

threshold' in the values was recognizable (especially at the highest flow of $20 \mathrm{~cm} \mathrm{~s}^{-1}$, between the 3 highest densities $\left(1200,1000\right.$ and 800 shoots $\left.\mathrm{m}^{-2}\right)$ and the 2 lowest ( 600 and 400 shoots $\mathrm{m}^{-2}$ ). These results support most of our initial hypotheses. One must remember, however, that these observations concern only a $15 \mathrm{~cm}$ wide, $1 \mathrm{~m}$ long bed of small, juvenile Zostera plants and that large plants and a larger bed may behave differently. Further, wind-generated waves, not considered here, can have great influence and may cause other flow patterns.

Because of differences in flume scalings and experimental conditions, comparison with previous flume 
work is difficult. Fonseca et al. (1982) found significant correlations between $U_{*}^{*}$ and shoot density in a $50 \mathrm{~cm}$ long Zostera meadow, and no pattern of flux reduction as a function of velocity. In a recent paper Fonseca \& Kenworthy (1987, p. 62, Fig. 2) presented some velocity profiles in different seagrass species and at different distances into the meadow The shapes of the profiles were very different from ours, but their flume conditions were unspecified.

Ackerman $(1983,1986)$ calculated a 10 -fold reduction of water speed within an eelgrass bed in the field compared to that outside of the bed. In another field study Fonseca et al. (1983) found a significant, negative correlation between U* and distance into the meadow at low flow ( $<53 \mathrm{~cm} \mathrm{~s}^{-1}$ in their classification); no correlations were found at medium and high velocities $\left(>53 \mathrm{~cm} \mathrm{~s}^{-1}\right)$. We are concerned in particular that their Froude number scaling may have been in substantial disagreement with field conditions. Eckman (1987) showed that speed reduction inside a bed was greater where shoot density was higher.

Eckman (1987) calculated water flux from 4 velocity profiles in 2 Zostera marina natural beds with high ( 600 to 1000 shoots $\left.\mathrm{m}^{-2}\right)$ and low (180 to 270 shoots $\mathrm{m}^{-2}$ ) shoot density subjected to 2 different flow regimes (defined as slow and fast current). He found $84 \%$ flux reduction below the canopy between low- and high-density sites at low flow speeds, and $48 \%$ reduction in fast currents. Our data do not exhibit a monotonic decrease of flux among densities with increasing free-stream velocity. Maximal flux reduction occurred at the highest density (1200 shoots $\mathrm{m}^{-2}$ ) and at $20 \mathrm{~cm} \mathrm{~s}^{-1}$ (Table 4B). Further in situ and flume measurements are necessary, however, to better evaluate the relationship between flux reduction, shoot density, flow depth and ambient velocity

No previous evaluations of turbulence intensity have been made in seagrass beds. Our data show a dramatic increase of turbulence at the canopy-water interface and within the canopy due to flow disruption by the canopy. Turbulence is not only generated (in the case of laminar flow) but likely rescaled (in the case of turbulent flow).

\section{Ecological implications}

These flow modifications and flow patterns influence many of the environmental characteristics of eelgrass beds, such as suspended sediment concentration within the bed, diffusion of dissolved gases to and from the plants, and nutrient exchange to and from the sediment-water interface. These environmental features, as well as the direct action of shear stresses, have important ecological implications for the plants themselves as well as their associated organisms.
Water movement can have strong influence on seagrass production, growth rate and photosynthesis (Fonseca \& Kenworthy 1987 and references therein), mainly due to changes in the diffusive boundary layer thickness. Dissolved gases for photosynthesis $1 \mathrm{O}_{2}$ and $\mathrm{CO}_{2}$ ), as well as nutrients, need to cross this layer of stagnant water by molecular diffusion, and this process can limit the rate of photosynthesis (Dennison \& Barnes 1988, Koehl \& Alberte 1988). Exchange of these dissolved substances can be enhanced by increasing water speed or turbulence intensity.

An important indirect influence on plant photosynthesis, related to the possibly greater load of suspended material supported via turbulence at the water-canopy interface, would be to increase the light intensity gradient along the Zostera marina canopy (Mazzella \& Alberte 1986). Both the light intensity gradient and day length influence photosynthesis of this plant, especially at greater depths (Dennison \& Alberte 1982, 1985, Mazzella \& Alberte 1986). Modifications toward further reduction of light intensity within the canopy could have dramatic effect on plant photosynthetic efficiency and even survival (Alberte pers. comm.).

Current patterns also have strong implications for plant pollination, as observed by Ackerman (1983, 1986). Turbulence intensity and flow deflection above the canopy can affect pollen transport and pollen interception by female organs (carpels), even at low Reynolds numbers.

Many authors (Molinier \& Picard 1952, Blois et al. 1961. Chassé 1962, Den Hartog 1971, Blanpied et al. 1979, Boudouresque et al. 1985) have pointed out in a qualitative manner a relationship between shape and structure of the beds and hydrodynamics in different species of seagrass. For Zostera marina beds in particular, Den Hartog (1971) stated that 'Zostera beds are in the state of continual change, being built up in one place and broken down in another, but there is dynamic equilibrium between these two processes'. Fonseca et al. (1983) observed a positive correlation between patchiness of Zostera beds and current strength. Erosion of the beds can be due to wave and tidal action in 'weak' places (Den Hartog 1971) or to high sedimentation rates and consequent burial of the plant. Our data suggest that flow acceleration around the canopy, coupled with turbulence and wakes to the rear of the beds can cause local erosion. These phenomena can contribute to produce the 'zigzag' and 'leopard skin' (small atolls) patterns of beds observed in many species of seagrass where waters usually are calm (Molinier \& Picard 1952, Chassé 1962, Calvo \& Frada-Orestano 1984).

Organisms living on or between seagrass leaves are generally very specialized and often are found exclusively there (Kikuchi \& Peres 1977, Boero 1981, Fresi et 
al. 1982, Thayer et al. 1984, Casola et al. 1987, Mazzella et al. 1989). In contrast, organisms inhabiting seagrass rhizomes or prairie bottom (below canopy) are less specialized and can also occur in other kinds of environments (Boudouresque et al. 1981, Pansini \& Pronzato 1985). This difference can be due to the physically unique habitat of seagrass blades (Gambi et al. in press).

Many authors have pointed out that species richness and abundances of organisms in seagrass meadows are functions of plant density or plant surface area per unit of bottom area (Heck \& Orth 1980, Orth et al. 1984). Most of the experimental studies have focused on the role of higher plant density in reducing predation on invertebrates and fish juveniles (Young \& Young 1978, Nelson 1981, Summerson \& Peterson 1984, Bell \& Westoby 1986 and references therein). Other studies (Eckman 1987) suggest, however, that increased attention has to be given to the effects of higher leaf density in reducing shear stress at the bottom, enhancing fine sediment and organic matter deposition and in this way favoring a larger number of species and individuals. Seagrasses baffling the current and acting as 'sediment traps', easily can 'trap' larvae of invertebrates and fishes as well (Eckman 1983, Butman 1987).

Flux reduction within the meadow can limit the development, abundance or growth of filter-feeding organisms, especially the 'passive' forms (sensu La Barbera 1984). On the other hand, turbulence, increasing within the canopy, can augment residence time of organic material in suspension within the canopy or resuspend deposited seston, as observed with animal tubes (Carey 1983, Eckman \& Nowell 1984). This phenomenon can balance the negative effects of flux reduction on filter-feeding activity, as hypothesized by Peterson et al. (1984), who studied the growth rate of a filter-feeding bivalve (Mercenaria mercenaria) within and outside an eelgrass meadow. Growth rates and mean sizes of these bivalves were in fact, greater inside the bed than outside it, despite fluid flux reduction (Peterson et al. 1984). Shoot density, distance into the meadow from the bed edge and ambient current regime are therefore very important features to consider in studies on feeding guild characterization and food web dynamics within seagrass beds.

In conclusion, Zostera marina plants interact strongly with flow, extracting momentum from the fluid via hydrodynamic drag and generating turbulence via flow disruption. Current and flux reduction, shear stress at the canopy level and turbulence intensity are positively correlated with plant abundance. These observations are consistent with boundary layer theory and with most of the mechanisms often invoked 'intuitively' to explain the distributional patterns of sediments and organisms in eelgrass meadows. Flow modifications in eelgrass, as well as in other seagrasses, however, are far from being exhaustively described and understood. In situ measurements are absolutely necessary to verify flow patterns observed in the flume, and to determine their ecological significance.

Acknowledgements. Thanks are due to the Director of the Friday Harbor Laboratories (University of Washington) for use of facilities. We thank also Mr Robert (Liko) Self, Ms Patricia Yager, Dr David Wethey and Dr James Eckman for their valuable discussions and technical help. Dr M. C. Gambi was supported by the Stazione Zoologica of Naples and by a Fulbright fellowship. Equipment for this study and participation of the 2 co-authors (A.R.M.N. and P.A.J.) was funded by ONR contract N00014-87-K-0160 and NSF Grant OCE 8608157.

\section{LITERATURE CITED}

Ackerman, J. D. (1983). Current flow around Zostera marina plants and flowers: implications for submarine pollination. Biol. Bull. mar. biol. Lab., Woods Hole 165: 504

Ackerman, J. D. (1986). Mechanistic implications for pollination in the marine angiosperm Zostera marina. Aquat. Bot. 24: 343-353

Bell, J. D., Westoby, M. (1986). Importance of local changes in leaf height and density to fish and decapods associated with seagrasses. J. exp. mar. Biol. Ecol. 104: 249-274

Blanpied, C., Burrolet, P. F., Clairefond, P., Shimi, M. D. (1979). La mer pélagienne. III Sédiments actuels et holocènes. Ann. Univ. Provence 6 (1): 61-83

Blois, J. C., Frabcaz, J. M., Gaudichon, S., Le Bris, L. (1961). Observations sur les herbiers à zostères de la region de Roscoff. Cah. Biol. mar 2: 223-262

Boero, F. (1981). Systematics and ecology of the hydroid population on two Posidonia oceanica meadows. P.S.Z.N.I.: Mar. Ecol. 2 (3): 181-197

Boudouresque, C. F., Cinelli, F., Fresi, E., Mazzella, L., Richard, M. (1981). Algal undergrowth of Posidonia oceanica beds in the Gulf of Naples: floristic study. Rapp. P.-v. Réun. Comm. int. Explor. scient. Mer Méditerr. 27 (2): 195-196

Boudouresque, C. F., Jeudy de Grissac, A., Meinesz, A. (1985). Un nouveau type d'herbier à Posidonia oceanica: l'herbier de colline. Rapp. P.-v. Réun. Comm. int. Explor scient. Mer Méditerr. 29 (5): 173-175

Butman, C. A. (1987). Larval settlement of soft-sediment invertebrates: the spatial scales of pattern explained by active habitat selection and the emerging role of hydrodynamical processes. Oceanogr. mar. Biol. A. Rev. 25: 113-165

Calvo, S., Frada-Orestano, C. (1984). L'herbier à Posidonia oceanica des côtes siciliennes: les formations récifales du Stagnone. In: Boudouresque, C. F., Jeudy de Grissac, A., Olivier, J. (eds.) Int. Workshop on Posidonia oceanica beds, Vol. 1. Gis Posidonie, Marseille, p. 29-37

Carey, D. A. (1983). Particle resuspension in the benthic boundary layer induced by flow around polychaete tubes. Can. J. Fish. Aquat. Sci. 40 (suppl.): 301-308

Casola, E., Scardi, M., Mazzella, L., Fresi, E. (1987). Structure of epiphytic community of Posidonia oceanica leaves in a shallow meadow. P.S.Z.N.I.: Mar. Ecol. 8 (4): 285-296

Chassé, C. (1962). Remarque sur la morphologie et la bionomie des herbiers des Monocotyledones marines 
tropicales de la province de Tuléar (Republique Malgache). Rec. Trav. Stn mar Endoume; Suppl. 1, Trav. Stat. mar. Tuléar: $237-248$

Cionco, R. M. (1983). On the coupling of canopy flow to ambient flow for a variety of vegetation types and densities. Boundary Layer Meteorology 26: 325-335

Den Hartog, C. (1971). The dynamic aspect in the ecology of seagrass communities. Thalassia jugosl. 7 (1): 101-112

Den Hartog, C. (1977). Structure, function and classification in seagrass communities. In: McRoy, P., Helfferich, C. (eds.) Seagrass ecosystem: a scientific perspective. Marine Science 4. Marcel Dekkar, Inc., New York, p. 90-121

Dennison, W. C., Alberte, R. S. (1982). Photosynthetic responses of Zostera marina L. (eelgrass) to 'in situ' manipulations of light intensity. Oecologia (Berl.) 55: 137-144

Dennison, W. C., Alberte, R. S. (1985). Role of daily light period in depth distribution of Zostera marina (eelgrass). Mar Ecol. Prog. Ser. 25: 51-61

Dennison, W. C., Barnes, D. J. (1988). Effect of water motion on coral photosynthesis and calcification. J. exp. mar Biol. Ecol. 115: 67-77

Eckman, J.E. (1983). Hydrodynamic processes affecting benthic recruitment. Limnol. Oceanogr 28 (2): 241-257

Eckman, J. E. (1987). The role of hydrodynamics in recruitment, growth and survival of Argopecten irradians (L.) and Anomia simplex (D'Orbigny) within eelgrass meadows. J. exp. mar. Biol. Ecol. 106: 165-191

Eckman, J. E., Nowell, A. R. M. (1984). Boundary skin friction and sediment transport about an animal tube mimic. Sedimentology $31: 851-862$

Fonseca, M. S., Fisher, J. S. (1986). A comparison of canopy friction and sediment movement between four species of seagrass with reference to their ecology and restoration Mar. Ecol. Prog. Ser. 29: 15-22

Fonseca, M. S., Fisher, J. S., Zieman, J. C., Thayer, G. W (1982). Influence of the seagrass Zostera marina $\mathrm{L}$. on current flow. Estuar. cstl Shelf Sci. 15: 351-364

Fonseca, M. J., Kenworthy, W. J. (1987). Effects of current on photosynthesis and distribution of seagrasses. Aquat. Bot $27 \cdot 59-78$

Fonseca, M. S., Zieman, J. C., Thayer, G. W., Fisher, J.S (1983). The role of current velocity in structuring eelgrass (Zostera marina) meadows. Estuar. cstl Shelf Sci. 17 $367-380$

Fresi, E., Chimenz, C., Marchio, G. (1982). Zonazione di Briozoi epifiti in una prateria di Posidonia oceanica (L.) Delile. Naturalista sicil. S, IV, VI (Suppl.) 3: 499-508

Gambi, M. C. (1986). The field method of 'plaster balls' for water movement estimates applied to Posidonia oceanica beds. Rapp. P.-v. Réun. Comm. int. Explor scient. Mer Méditerr. 30 (2): 89

Gambi, M. C. (1988;. Flowering in a Zostera marina bed off San Juan Island (Washington, U.S.A.) dunng winter Aquat. Bot. 30: 267-272

Gambi, M. C. (in press). Approccio teorico-sperimentale ed implicazioni ecologiche nello studio delle interazıoni tra idrodinamismo e benthos: un esempio con le fanerogame marine. In: Bregant, D., Fornzutti, G. P. (eds.) Proceedings of the 8th congress of the Italian Society of Oceanology and Limnology, Pallanza (Italy), 1988

Gambi, M. C., Lorenti, M. (1988). An application of a portable current meter for flow measurements near bottom by SCUBA diving. Rapp. P.-v. Réun. Comm. int. Explor scient. Mer Méditerr. 31 (2): 315

Gambi, M. C., Buia, M. C., Casola, E., Scardi, M. (In press) Estimates of water movement in Posidonia oceanica beds: a first approach. In: Boudouzesque, C. F., Fresi, E.
Meihesz, A. (eds.) 2nd. int. Workshop on Posidonia oceanica beds, Ischia (Naples) 1985. GIS Posidonie, Marseille

Ginsburg, R. N., Lowenstam, H. A. (1958). The influence of marine bottom communities on the depositional environment of sediments. J. Geol. 66: 310-318

Heck, K. L. Jr., Orth, R. J. (1980). Seagrass habitats: the roles of habitat complexity, competition and predation in structuring associated fish and motile macroinvertebrate assemblages. In: Kennedy, V. S. (ed.) Estuarine perspectives. Academic Press, New York, p. 449-464

Hill, P. S., Nowell, A. R. M., Jumars, P. A. (1989). Flume evaluation of the relationship between suspended sediment concentration and excess boundary shear stress. J. geophys. Res. 93: 12499-12509

Jackson, G. A., Winant, C. D. (1983). Effect of a kelp forest on coastal currents. Cont. Shelf Res. 2 (1): 75-80

Jeudy de Grissac, A. (1984). Effects des herbiers a Posidonia oceanica sur la dynamique marine et la sedimentologie littorale. In: Boudouresque, C. F., Jeudy de Grissac, A., Olivier, J. (eds.) Int. Workshop on Posidonia oceanica beds, Vol. 1. Gis Posidonie, Marseille, p. $437-443$

Kikuchi, T (1980). Faunal relationships in temperate seagrass beds. In: Phillips, R. C., McRoy, C. P. (eds.) Handbook of seagrass biology: an ecosystem perspective. Garland STPM Press, New York, p. 153-172

Kikuchi, T., Peres, J. M. (1977). Consumer ecology of seagrass beds. In: McRoy, P., Helfferich, C. (eds.) Seagrass ecosystem: a scientific perspective. Marine Science 4. Marcel Dekkar, Inc., New York, p. 147-193

Koehl, M. A. R., Alberte, R. S. (1988). Flow, flapping, and photosynthesis of Nereocystis leutkeana: a functional comparison of ondulate and flat blade morphologies. Mar. Biol. 99: $435-444$

La Barbera, M. (1984). Feeding currents and particle capture mechanisms in suspension feeding animals. Am. Zool. 24 $71-84$

Madsen, T V., Warnke, E., (1983). Velocities of currents around and within submerged aquatic vegetation. Arch. Hydrobiol. 97: 389-394

Mazzella, L., Alberte, R. S. (1986). Light adaptation and the role of autotrophic epiphytes in primary production of the temperate seagrass: Zostera marina L. J. exp. mar. Biol. Ecol. 100: 165-180

Mazzella, L., Scipione, M. B., Buia, M. C. (1989). Spatio-temporal distribution of algal and animal communities in a Posidonia oceanica meadow. P.S.Z.N. I: Mar. Ecol. 10 (2): 107-129

Molinier, R., Picard, J. (1952). Recherches sur les herbiers de phanerogames marines du littoral mediterranéen français. Annls Inst. océanogr 27: 157-234

Nelson, W. G. (1981). Expermental studies of decapods and fish predation on seagrass macrobenthos. Mar. Ecol. Prog. Ser. 5: $141-149$

Nowell, A. R. M., Jumars. P. A. (1987). Flumes: theoretical and experimental considerations for simulation of benthic enviromments. Oceanogr. mar Biol. A. Rev. 25: 91-112

Nowell, A. R. M., Jumars, P. A., Southard, J. B. (in press). Responses of intertidal macrofauna to ripple migration in a laboratory racetrach flume. In: Lopez S. R. (ed.) Marine deposit feeding. Springer Verlag, New York

Ogden, J. C. (1980). Faunal relationships in Caribbean seagrass beds. In: Phillips, R. C., McRoy, C. P. (eds.) Handbook of seagrass biology: an ecosystem perspective. Garland STMP Press, New York, p. 1.73-198

Oliver, H. R. (1971). Wind profiles in and above a forest canopy. Q. J. R. Met. Soc, 97: 548-553 
Orth, R. J. (1973). Benthic infauna of eelgrass, Zostera marina, beds. Chesapeake Sci. 14: 258-269

Orth, R. J. (1977). The importance of sediment stability in seagrass communities. In Coull, B.C. (ed.) Ecology of marine benthos. Univ, of $\mathrm{S}$. Carolina Press, Columbia, $\mathrm{p}$. $281-300$

Orth, R. J., Heck, K. L., Van Montfrans, J. V (1984). Faunal communities in seagrass beds: a review of the influence of plant structure and prey characteristics on predator-prey relationships. Estuaries 7: 339-350

Ott. J. (1967). Vertikalverteilung von Nematoden in Beständen nordadriatischer Sargassaceen. Helgoländer wiss. Meeresunters. 15: 412-428

Pansini, M., Pronzato, R. (1985). Distribution and ecology of epiphytic Porifera in two Posidonia oceanica (L.) Delile meadows of the Ligurian and Tyrrhenian sea. P.S.Z.N.I.: Mar. Ecol. 6 (1): 1-11

Peterson, C. H., Summerson, H. C., Duncan, P. B. (1984). The influence of seagrass cover on population structure and individual growth rate of a suspension-feeding bivalve, Mercenaria mercenaria. J. mar. Res. 42: 123-138

Scoffin, T P. (1970). The trapping and binding of subtidal carbonate sediments by marine vegetation in Bimini Lagoon, Bahamas. J. sedim. Petrol. 40: 249-273

This article was submitted to the editor
Shaw, R. H., Silversides, R. H., Thurtell, G. W. (1974). Some observations of turbulence and turbulent transport within and above plant canopies. Boundary Layer Meteorology 5 : $429-449$

Shaw, R. H., Tavagar, J., Ward, D. P. (1983). Structure of Reynolds Stress in a canopy layer. J. Clim. appl. Met. 22: 1922-1931

Stoner, A. W., Lewis, F. G. (1985). The influence of quantitative and qualitative aspects of habitat complexity in tropical seagrass meadows. J. exp. mar. Biol. Ecol. 94: 19-40

Summerson, H. C., Peterson, C. H. (1984). Role of predation in organizing benthic communities of a temperate-zone seagrass bed. Mar. Ecol. Prog. Ser. 15: 63-77

Thayer, G. W., Kenworthy, J. W., Fonseca, M. S. (1984). The ecology of eelgrass meadows of the Atlantic coast: a community profile. U.S. Fish Wildl. Serv. FWS/OBS 84/02: 1-147

Thistle, D., Reidenauer, J. A., Findlay, R. H., Waldo, R. (1984). An experimental investigation of enhanced harpacticoid (Copepoda) abundances around isolated seagrass shoots. Oecologia (Berl.) 63: 295-299

Young, D. K., Young, M.W. (1978). Regulation of species densities of seagrass-associated macrobenthos:evidence from field experiments in the Indian River estuary, Florida J. mar. Res. 36: 569-593

Manuscript first received: August 12, 1988

Revised version accepted: September 29, 1989 